\title{
Safe Areas in Bosnia-Herzegovina: Some Reflections and Tentative Conclusions
}

\author{
Michael Barutciski
}

The UN operation in former Yugoslavia has been the object of much criticism. Some of the criticism has focused on the alleged ineffectiveness of the new concept of Safe Areas that has been applied in Bosnia-Herzegovina (BiH).

Any analysis of the contribution of the 6 Safe Areas in BiH (Srebrenica, Zepa, Gorazde, Sarajevo, Tuzla and Bihac) should take into account two inescapable facts relating to physical safety: $\mathrm{BiH}$ 's Muslim refugees and displaced persons are returning or going to some of the Safe Areas in $\mathrm{BiH}$; and UNHCR + UNPROFOR field personnel constantly assert that Safe Areas have saved lives.

It should be remembered that the Safe Areas were declared in a highly charged political context where there was considerable international pressure on the UN Security Council to intervene in favour of one of the parties in the armed conflict in $\mathrm{BiH}$. By declaring that certain localities that were controlled by the Muslims were to "be treated as Safe Areas by all parties concerned," the UNSC hoped to achieve at least three objectives:

- offer protection for threatened civilian populations;

- relieve pressure on it to intervene more forcefully and directly in favour of the Muslims by appearing to take a position against the Serbs;

- assist the Muslims by attributing to them a minimal amount of territory in anticipation of the inevitable partition of $\mathrm{BiH}$.

There were other towns and cities that were threatened by the Muslim forces (Doboj, Brcko) or being slowly destroyed by both the Croat and Muslim

Michael Barutciski is the Atle Grahl-Madsen Fellow in Law at Centre for Refugee Studies, York University. This work is based on his recent field visit to the Former Yugoslavia. forces (Mostar), yet these did not warrant the attention of the international news media or the UNSC. Safe Areas were therefore declared to directly help certain threatened populations and one party (Muslim forces loyal to $\mathrm{BiH}$ President Izetbegovic) in an internal armed conflict that involved at least two other parties.

It should be kept in mind that the initial UNSC resolutions (819 \& 824) declaring the Safe Areas did not commit the UN to militarily defend those areas. It was only later that the UNSC decided to allow a dramatic extension of UNPROFOR's mandate (resolution 836) by enabling it "to deter attacks against the Safe Areas," thereby allowing for the possibility of UNPROFOR to become a belligerent force in the $\mathrm{BiH}$ conflict and consequently losing its impartiality. Without total impartiality, UNPROFOR places its other missions (monitoring, delivering humanitarian relief, etc.) in jeopardy. UN member states did not, however, proceed in equipping UNPROFOR so that it could "deter attacks" against the Safe Areas. In addition, UNPROFOR Commanders have constantly made it clear that they are not particularly inclined to enter the war on the side of the Muslims, given their experience and assessment of the armed conflict in $\mathrm{BiH}$. The NATO military exclusion zones that were later created around two of the Safe Areas permitted the international community to get around this obstacle and back up the Safe Area declarations with military force while keeping UNPROFOR's impartiality relatively intact.

One of the consequences of the decision to declare Safe Areas that could not have been ignored by members of the UNSC was the manner in which these areas have reinforced and encouraged population shifts. Since the beginning of the armed conflict, $\mathrm{BiH}$ has been violently transformed and divided by the three warring nationalities (Muslim, Serb and Croat) into ethnically homogeneous territories. With the declaration that certain Muslim-controlled areas are to be considered "Safe Areas," displaced Muslim civilians have either been drawn to these Safe Areas or literally trapped in them by their own forces (escape would weaken Muslim territorial claims) while the Serb civilians that once inhabited them $(15-30 \%$ of the total prewar population depending on which Safe Area) have no illusions that they will be returning to them. Given that $\mathrm{BiH}$ could not be kept together as a unitary state following the break-up of the former Yugoslavia, this is not a negative development in that it encourages the division of $\mathrm{BiH}^{\prime}$ 's territory among the three nationalities and thus brings the parties closer to a solution.

There will be a tendency for some to see Safe Areas as the latest example of western containment of refugee flows. This view should be nuanced, for it is unlikely that containment was a primary consideration for the UNSC. As mentioned above, Safe Areas in the case of $\mathrm{BiH}$ (to be distinguished from the situation in Iraq or Rwanda) should be understood primarily as a political tool meant to show support for one of the parties in the conflict. That the creation of Safe Areas had consequences on the displacement of civilian populations and refugee flows is evident. However, several factors suggest that containment of refugee flows could not have been a principal objective of powerful and affluent states. Firstly, contrary to the situation in Iraq and Rwanda, Safe Areas were not created in border regions with thousands of uprooted civilians intent on crossing into neighbouring coun- 
tries. Secondly, Safe Areas were created some 15 months after hostilities began and much of the displacement had already occurred. Thirdly, by the time Safe Areas were declared, Serbia and Croatia had already closed their borders to Muslims fleeing $\mathrm{BiH}$, thereby greatly reducing the threat that Europe would be confronted with a large influx of BiH's Muslims. Fourthly, contrary to the logic of containment, several northwestern European states continued not to require visas from $\mathrm{BiH}$ passport holders months after Safe Areas were declared.

A closer examination of the situation in each particular Safe Area also gives some insight on the possible contribution and weaknesses of this new concept. By declaring the town of Srebrenica to be a Safe Area, the UNSC prevented the Serbs from taking it and forcing the Muslim civilians to flee to the nearby cliffs around the village of Zepa. The arrival of several tens of thousands of displaced persons into the sparsely inhabited and resourceless Zepa area would have created a humanitarian crisis much worse than the one presently experienced by UNHCR in Srebrenica. Most importantly, the Muslim leadership will now be able to negotiate a territorial exchange agreement whereby they can abandon the isolated enclaves of Srebrenica and Zepa in exchange for Sarajevo.

Consequently, the concerned civilian populations will be transported and exchanged in a more secure and orderly fashion. This potential longterm solution for the displaced persons and local inhabitants of Srebrenica and Zepa also highlights the temporary nature of the response provided by the declaration of Safe Areas. The strong Muslim military presence in the
Gorazde pocket suggests that the Muslims may not be willing to include Gorazde in a territorial exchange agreement, but rather, may try to link this enclave with the Sarajevo region, as was originally proposed in the latest Peace Plan by the Contact Group (USA, UK, France, Germany and Russia).

The highly mediatized Sarajevo area will most likely be included in a territorial exchange agreement as it is becoming more ethnically homogeneous: the Serbs and Croats who have fled have been replaced by Muslims who have come to seek refuge in the city and its suburbs.

The Bihac Safe Area illustrates one important problem if Safe Areas are to work in the future. The Bihac pocket had been relatively safe until August 1994, when the BiH Fifth Corps (Muslims loyal to President Izetbegovic) launched an offensive from the Safe Area and took over the whole Bihac pocket by defeating a rebel Muslim army, loyal to local businessman Fikret Abdic, and forcing 30,000 Muslim refugees to flee to the neighbouring UN Protected Area in Croatia. In Octo- ber, the 5th Corps launched a new offensive from the Safe Area and managed to seize territory from the Serb forces to the south and to the east of the Safe Area (displacing 15,000 Serbs). In the middle of November, Serbs from $\mathrm{BiH}$ and Croatia together with Abdic's rebel Muslims launched a counter-offensive, regained most of the lost territory, and began threatening to take over the Safe Area. The international news media then proceeded to criticize UNPROFOR and NATO for not defending a UN-designated Safe Area while seemingly ignoring a fundamental problem: it is difficult for the international community to deter attacks against Safe Areas if they are being used by a belligerent in order to launch offensives.

The same problem exists regarding the Tuzla Safe Area with the exception that the Muslim forces continue to be firmly in control of the surrounding territory. Military activity around/ within Safe Areas (including the frequent Serb harassment of the populations within these areas) must be addressed in order to increase the usefulness of Safe Areas as a form of protection for civilian populations threatened by displacement. Demilitarization appears to be one essential condition to make Safe Areas serve their temporary role. Otherwise, Safe Areas are likely to mirror armed conflicts in that they will be full of violations, abuse, and manipulation.

There are many lessons to be learned from the UN's experience with the Safe Area concept. Despite the many problems associated with this concept, the case of $\mathrm{BiH}$ suggests that it may have a positive role to play and can contribute toward solutions to problems that cause refugee flows. 
Refuge York Lanes Press Centre for Refugee Studies Suite 351, York Lanes York University 4700 Keele Street, North York Ontario, Canada M3J 1P3 Phone: (416) 736-5843 Fax: (416) 736-5837 Internet: refuge@vm1.yorku.ca

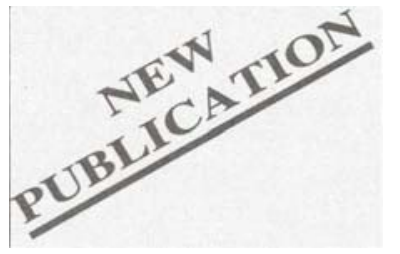

Every year the refugee landscape changes, but only in that more problems are added, fewer are solved, and all become constantly more urgent. Fuelled by the explosion of the world $s$ population, the quest for asylum is one of the most pressing problems of our age. Refugee receiving nationslocated frequently, but by no means exclusively, in the Western worldhave to respond to masses of humanity searching for new livable homes. Human compassion for these refugees can be found everywhere, but so can xenophobia and the desire to preserve one's nation, economic well being, and cultural integrity. The clash between these impulses represents one of the great dilemmas of our time and is the subject of Plaut's study. In exploring it, he provides a far-ranging inquiry into the human condition.

The book presents political, ethnic, philosophical, religious, and sociological arguments, and deals with some of the most troublesome and heanbreaking conflicts in the news.

Contents: Tbe Issues; Questions Without Answers; Definitions; Religion, Natural Law, and Hospitality; A Look

Available from: York Lanes Press, Suite 351, York Lanes, York University, Nonh York ON M3J IP3

Fax: (416) 736-5837 • Internet: refuge@vml. yorku. ca at History; Some Ethical Questions; Through the Lens of Sociobiology; Community and Individual; Contended Rights: To Leave, Return, Remain; Tbe Practice; Refugees in Africa; Four Asian Lands; Glimpses of Europe and Central America; The North American Experience; The Sanctuary Movement; A Final Look; Appendix A: Egyptian and Hittite Treaties; Appendix B: Human Rights-Major Documents; Appendix C: Refugee Documents; Protocol Relating to the Status of Refugees of 31 January 1967; Bibliography; Index.

W. Gunther Plaut is a senior scholar at the Holy Blossom Temple in Toronto. Born in Germany, where he received his doctor of laws, he fled Hitler's Reich for the United States where he became a rabbi, serving in Chicago, St. Paul, and since 1961 in Toronto. Plaut is the author of 19 books, including Torah: A Modern Commentary (with B. Bamberger). His recommendations on the refugee determination process, submitted in 1985 at the invitation of the Canadian government, had an impact far beyond Canada's shores.

Asylum is simultaneously published in the United States by Praeger Publishers. 